\title{
Selected Aspects of the Property Rights Regime in Slovenia in the Context of the EU
}

\author{
PhD (Uni Graz) Dr. Mag. lur (Uni Graz) Endri Papajorgjı \\ Karl Franzens Universität Graz, Universiteti Luarasi \\ endripapajorgji@hotmail.com
}

\section{Doi:10.5901/mjss.2014.v5n20p553}

\section{Abstract}

\begin{abstract}
Slovenia is member of the EU since 1.5.2004. It was an ex Republic of the Yugoslav federation that declared its independence on 25.6.1991. Slovene territory was part of the empire of Franks from 8th century then of the German empire till 1804 and Austrian empire till 1918. North-eastern part was part of Hungarian state and its successors from 9th century till 1918. Western part of Slovenia was part of Italy between 1918 and 1943. Slovenia became part of the Kingdom of Slovenes, Croats and Serbs from 1914/1929. After World War II it became part of Yugoslavia and its socalist legal system. The socialist legal system that was implemented in Slovenia as in all Republics of the Yugoslav federation was based in the building of state property, which was created by massive confiscations of the property of the so called collaborators in 1945 and then by three nationalization periods which took place between 1945 and 1956. After a difficult economic period, the Yugoslaw state implemented the new system of socialist self management, which meant that workers fullfill directly or equally their social-, economic- and selfadministering rights, and decide on issues dealing with the socio-economic situation of the enterprise. This legal system was also based in the building of state and social Property. In the late 80's an ideological, political, economic system disintegrated and in Slovenia as in all countries of Eastern Europe, democracy, free market economy and the rule of law, based on private property and free market economy were the foundation of the transformation. In this context this paper analyzes the transformation that took place in the property rights regime in Slovenia in a legal view in compliance with EU law.
\end{abstract}

Keywords: Property law, reform, Slovenia, Integration, EU.

\section{Introduction}

The Constitution of the Republic of Slovenia guarantees the right of property and determines that the property acquisition and disposal is guaranteed in such a way that the free economic, social and ecological disposition is protected. The property law that entered in force on $1.1 .2003^{1}$ (in below SCC) regulates the property rights, while the economic, social and ecological disposal of property is regulated in special laws. In the Slovenian property law another two obligation institutions are regulated, namely the disposal and encumbrance as well as the right to repurchase. The reason for this is that the legislator has failed to regulate both institutions in the Slovenian Obligations Law. The Slovenian Property law consists of eleven parts: basic principles, basic concepts, possession, property, home ownership, lien, mortgage, security transfer, easements, effective obligations, construction and final provisions.

The Slovenian Property law contains definitions of certain property law basic terms, the law of property, like the property, the parts, the accessories, etc. The thing is defined in Article 15 of SCC as an independent physical object a person can control (Papajorgji 2013). Similar to the German Civil Code and the Dutch Civil Code only physical objects are classified as things. Property rights are not objects and are treated only in certain cases as things. They can be the subject of a lien or fruit enjoyment. In line with the principle of specialty the immovable property in Article 18, paragraph 1 of SCC, is defined as a spatially-measured parts of the earth's surface together with all the ingredients. This definition coincides essentially with the definition of property in German law. The immovable property is classified equally with a plot or a parcel of land (Rudolf, Rijavec, Kerestes, 2008).

The Slovenian property law has introduced the German legislation point of view from 1980 that only "corpus" is required for possession, and not as the Austrian law that requires also animus possidendi. The literature in Slovenia speaks of subjective- (corpus and animus) and objective possession (only corpus) of the owner (Gärtner 1996). Following the example of $\S 872$ of the german BGB, Article 27 of the SCC differs between individually owned- and foreign-owned things. A Possessor in accordance with Article 27 para 1 is the one who has a thing in possesion. Foreign owner is in accordance with para 2, who posseses a thing without having the will belonging to the thing as him to possess, and which

\footnotetext{
${ }^{1}$ The Code of Obligations." No. 83/2001.
} 
recognizes the right of property by the indirect owner. The key therefore is the will, to posses' one thing as their own, which basically means "animus possidendi" and is in accordance with the German view of the property as a criterion for the definition of ownership (Messman 2000).

The Slovenian property law is "Germanic" oriented. It is similar to the German and Austrian law of the so-called separation principle from which distinguishes between commitment and disposal. Under the influence of the Austrian tradition there's a distinction in the Slovenian literature between titulus and modus aquirendi (Papajorgji 2012). The Slovenian property law has clearly decided in Article 40 SCC in favour of the system of causal tradition, so that a valid transfer of ownership needs a valid Title. The Slovenian property law notes in connection with the transfer of ownership following conditions that include:

- a valid legal transaction;

- a valid Purchase method, ie a disposal business and a Realakt, through which the publicity is guaranteed.

- the right of disposal of the transferor.

Immovable Properties are defined as spatially ciscumscribable parts of the ground surface and all ingredients that are intentionally connected permanently to land or permanently on, above or below the plot. The Slovenian immovables law generally applies the principle "superficies solo cedit", which is broken by two exceptions: the building right and the property floor. In the latter cases, the property falling apart at the building or parts of buildings and the ownership of the underlying land. Here are included the building or its parts that must be handled legally and registered independently (Rudolf, Rijavec, Kerestes, 2008). The right of property is the right to have one thing in possession, to benefit from it and in the broadest sense to dispose of it. The title to the property acquisition may be (such as adverse possession or superstructure of a building) a transaction, a disposition on death, a decree of state institutions or a legal arrangement. The mode of transfer of ownership of immovables due to a legal transaction is defined in the entry in the land register.

The unrestricted disposal right of the property owner may by limited by special laws, such as the Regional Planning Act, the law on forests or water supply. Limitations include the granting of compulsory pre-emption rights or the overriding requirement of an administrative authorization to transfer ownership. Foreigners can acquire ownership of immovables, only if they are to be entitled by law or by an international agreement in Slovenia (Rudolf, Rijavec, Kerestes, 2008). According to the Annex VIII of the EU Association Agreement, nationals of EU Member States since 1.2.2003, based on the principle of reciprocity, acquire immovables in Slovenia. Reciprocity is defined in the reciprocity Act and found concrete application by decision of the Ministry of Justice. The Ministry decides on the existence of reciprocity within 90 days of receipt of the complete application. Against such a decision no appeal is permitted. Therefore, the applicant is open to the only remedy of the administrative process. If foreign companies establish subsidiaries located in Slovenia, they can purchase immovables under the same conditions as Slovenian companies. Subsidiaries of foreign companies are entitled to the Property Acquisition, if they need the property to carry out those economic activities for which they were established (Papajorgi 2012). All natural persons who are not citizens of the Republic of Slovenia, as well as all legal entities established outside Slovenia are classified as foreigners.

The Institute of the land registry was introduced on the territory of the Republic of Slovenia in the 19th century. It is based on the Austro-German system of property evidence (Boric 1993). Since the entry into force of the Regulation on the management of the land register in electronic form and on the approximation of the data in the Land Register of the data in the land register in 2001, only the electronic land registry is basically used only. The rights of immovable are entered in the so-called ledgers, while the registration is preserved in the collection of documents. The internal organization of the land register is regulated in the Articles 49-62 of the Slovenian Land Registry. The general ledger is similar to the Austrian book, designed according to the real film system and is divided into 3 insert sheets: the A-sheet, which cointains information about the property; the B-sheet, where property rights are incorporated; and the C-sheet, where other rights are registered (Papajorgji 2013). The collection of documents consists of the records that are the basis for registration in the Land Register.

The documents collection is part of the ledger, ie it is subordinate to the general ledger and meets only one auxiliary function. The legal effects of registration are basically bound to the entry in the general ledger. The Slovenian Immovables registration right includes (Rudolf, Rijavec, Kerestes, 2008):

(A) the principle of constitutive effect of the entries for derivatively acquired real rights;

(B) the principle of legality: the making of entries only on the basis of legally defined documents, which must meet certain formal requirements;

(C) the formal principle of consensus: the declaration of the person whose rights are limited by registration, loaded or deleted;

(D) the principle of mandatory indication of land registry;

(E) the formal principle of publicity: the general ledger is public and accessible. 
In this sense the notation (adnotatio) is a registration or deletion fairly significant fact that does not relate to the acquisition, termination or restriction of rights. There are two types of comments: on the one hand notes that include personal circumstances of the owner of the registered rights (eg restrictions on capacity, appointment of a custodian) that have only a declarative character and on the other hand notes, which caused certain legal effects (Rudolf, Rijavec, Kerestes, 2008).

In addition to the property law under Article 10 of the law on Land also mandatory rights can be registered in the Land Registry that include: lease rights if the lease duration exceeds more than a year, the right of preemption, buy rights and disposal rights. The registration fee for annexations of property rights consists of a flat rate of approx. 90 Euros. The immovables transfer tax is $2 \%$ of the agreed purchase price. If the registration certificate is a private document, then the signature of the person that restricts its right of burden should be notarized. If there is an agreement on mutual recognition, a foreign notarized deed shall be recognized as a Slovenian notarized certificate (Papajorgji 2013). If an agreement on the mutual recognition doesn't exist, than the documents notarized abroad have to be confirmed by an apostille. On land registry are applied the rules of non-contentious procedure application. Such a decision may be appealed, over whom a judge has to decide. Against the decision of the judge of second instance an appeal can take place. The Slovenian land register law knows also the cancellation action. In this way the one who is injured in his rights by a land registration, seeks a declaration of invalidity of the annexation with lawsuit, if substantive reasons exist. At the same time the reinstatement of the land registry object has to be applied.

\section{Property Securities}

Slovenian law recognizes the following forms of securities that can be justified in real estate: lien (mortgage) and real charge. For effective reasons, they should be registered in the land register (constitutive activity).

For the mortgage, it is required a legal title (iustus titulus) and one of repurchase (modus aquirendi). During the registration of mortgage, the securities must be specified separately. The description includes the legal relationship from which the secured claim results, the amount of the claim expressed in a monetary unit, as well as their maturity. If it does not contradict mandatory rules, the requirement in the land register may be denominated in a foreign currency. Mortgage guarantees the mortgage creditor the preferential satisfaction from the proceeds of sale of property. The principle of extensivity states that a mortgage always covers the entire property and its fruits. If a collateralized by mortgage debt is partially paid, the mortgage is not reduced. The justification of mortgages to non-material co-ownership does not require the consent of the other co-owner (Rudolf, Rijavec, Kerestes, 2008). The Slovenian Property Law recognizes both the simultaneous mortgage as well as the maximum amount mortgage. Since a mortgage is an accessory security, this means that the transfer of a mortgage to another mortgage creditor can be realized only by a transfer of the secured claim itself.

The assigner receives its authority from the mandatory law. For the assignment of the obligation under Article 436 of the Slovenian obligations law the consent of the debtor is not required. Article 437 of the Slovenian obligations law expressly provides that an assignment with the requirement also merges the subsidiary rights to the transferee. It can be assumed that also due but not yet paid interests are assigned with the principal claim. Basically, the mortgage creditor will have to make his claim in court, where inventory and due date are proof of the claim. The judgment of the Court is then the writ of execution, the right to initiate the execution process for the recovery of the mortgaged property (Papajorgji 2013). However, if the pledge agreement was concluded in an immediately enforceable notary form, it applies in the event of default as executory title and allows for a prompt application to initiate enforcement proceedings.

Because the pledged property remains in the possession of the mortgage debtor, this or a third party can reduce the value of the land affected by the mortgage property or otherwise worsens their condition. The mortgage creditor can bring in this case to the court an action for an injunction to such acts by the debtor. If a property is burdened with multiple mortgages, then - unless the law provides no derogation - it is relevant for their rank order the time of their inception. For the creation of the mortgage, it is important the date in which the application was introduced for registration at the land registry court. If multiple applications were implied simultaneously, then they are classified as the same rank.

The foreclosure process for immovables is characterized by the following steps: Notation of the enforcement decision in the land register, determining the value of the property, sale of property and the payment of creditors from the amount generated by the sale. At the first hearing the property must not fall under an established value, in the second the property shall not be sold less than half of its value and between the first and the second hearing at least 30 days should have passed. 


\section{Conclusions}

Slovenia s road toward the EU has been a long one. From this paper became evident that the property regime of Slovenia is regulated in compliance with the EU law. The changes that occurred in the property rights regime in Slovenia after the fall of communism are substantial, because during socialism social property had a privileged position in comparison to private property. The Slovenian property law shows an Austrian and German influence that is also closely connected with the history of Slovenia before communism.

As it became clear from this article the title of ownership is transferred to the buyer upon its registration in the Land Registry. The priority of certain rights over other ones is governed by the ranking as registered in the Land Registry. The right that has been registered earlier in the Land Registry has priority in ranking over the right registered at a later date. However, some rights are not registered in the Land Registries (e.g. statutory pre-emption rights). The main rule is that, in the event of conflict between a statutory and contractual right, the statutory right shall prevail. A written purchase contract is required and must, at a minimum, include the parties, the respective real estate and the purchase price. In order to register ownership, the seller must also provide a land registry permission whereby its signature must be notarised. A notary may notarise the signature only when proof that the real estate transfer tax has been paid is obtained (or in case of value added tax: an invoice is attached; or information from the invoice is included in the contract) and if the certificate on use (issued by the competent municipality) does not include any restrictions with respect to the transfer.

Apart from rights in rem (ownership, mortgage, land debt, easement, right of encumbrance and building right), obligatory rights are recognised. Obligatory rights on real estate are, inter alia, the right to prohibit alienation or encumbrance, the right to lease or rent, a contractual pre-emption or redemption right and a special right to use a public asset. In addition, divided co-ownership (condominium) and building right are the only rights in rem where the principle of superficies solo cedit is not followed.

\section{References}

Borić, T. (1993), Entwicklung der Unternehmensumwandlung und Privatisierung in Kroatien, Slowenien und Ungarn. Privatisierung in Ungarn, Kroatien und Slowenien im Rechtsvergleich, 134-145. Vienna.

Gärtner, W. (1996), Die Eigentumsgarantien in den Verfassungen Polens, Ungarns, der Tschechischen und der Slowakischen Republik. Verfassungsrechtliche Grundlagen und Verfassungspraxis, Eigentum in Osteuropa. Peter Lang, Berlin, 219-232. Berlin.

Messman, S. (2000), Die Errichtung einer Tochtergesellschaft in Jugoslawien. Zeitschrift für Unternehmens- und Gesellschaftsrecht, Berlin, 490-502. Berlin.

Papajorgji, E. (2012), E drejta ndërkombëtare tregtare dhe e biznesit. Tiranë.

Papajorgji, E. (2012), E drejta europiane private. Tiranë.

Papajorgji, E. (2013), Privatisierung von Unternehmen in Albanien und Mazedonien im Rechtsvergleich. Saarbrücken.

Rudolf, C. Rijavec, V. Kerestes, T. (2008), in Wolfgang Faber, Brigitta Lurger, National reports on the transfer of movables in Europe (Austria, Estonia, Italy, Slovenia).507-638. Vienna.

$\mathrm{SCC} /$ Slovenian Civil Code

ABGB/Austrian Civil Code.

BGB/ German Civil Code. 